Acta vet. scand. 1976, 1\%, 196—209.

From the Department of Pathology, the Department of Surgery and the Department of Biochemistry, Veterinary College of Norway, Oslo.

\title{
GLYCOGENOSIS IN THE DOG
}

\author{
By \\ Muhammad Rafiquzzaman, Rolf Svenkerud, Anders Strande \\ and Jens G. Hauge
}

RAFIQUZZAMAN, MUHAMMAD, ROLF SVENKERUD, ANDERS STRANDE and JENS G. HAUGE: Glycogenosis in the dog. Acta. vet. scand. 1976, 17, 196-209. - Four cases of a generalized form of glycogenosis occurring in German Shepherd dogs, all females, are described. Symptoms could be noticed as early as the age of two months and progressed slowly for months. They appeared as dizziness, muscular weakness, and in two of the cases as poor nutritional state. The abdomen became gradually distended. The main lesion seen at postmortem was a greatly increased liver size with some moderate liver fibrosis. Heavy deposits of a granular substance behaving as glycogen in histochemical tests and at electron microscopy were found in the hepatic cells, muscle fibres of the heart, skeletal and smooth muscles, and in nerve and glial cells of the central nervous system. The substance was lying freely dispersed in the cell cytoplasm without any indication of lysosomal storage. The disease of dogs does not seem to be fully comparable with any of the types observed in man, but is probably much related to Type III or Cori's Disease. Structure analysis of the deposits and enzyme investigations have been done and are published (Čeh et al. 1976).

storagedisease; glycogen; pathology; dog.

Pathological increase of glycogen content in certain organs is observed in connection with abnormalities in glycogen metabolism in glycogen storage disease (GSD). The GSD in man comprises a group of closely related disorders of genetic origin and due to certain enzyme deficiencies (for lit. see di Sant'Agnese et al. 1950, Cori 1957, di Sant'Agnese 1959, Hers 1964, Howell 1972). According to Howell eight types of GSD have been reported. Some authors have, however, suggested some additional types and subtypes (Hug et al. 1966).

Though various types of GSD have received considerable attention and are fairly well documented in man, reports of the 
disease occurring in domestic animals are scarce. Bardens et al. (1961) published a paper on a type of hypoglycaemia seen in puppies of toy breeds, six to 12 weeks old which he thought to be similar to von Gierke's Disease in man. The condition differed from the human disease in the acuteness of the symptoms and in the response to treatment. The authors ascribed the condition to various stress factors. They reported a marked enlargement of liver cells resulting in the compression of the sinusoides. Renal lesions included swelling of the tubular, epithelial cells with narrowing of the lumen. In some cases, glycogen deposition was noted in the myocardium.

On the basis of information obtained by using the glucagon tolerance test on clinically suspected cases, Bardens (1966) in a later paper suggested the existence of three types of canine GSD: Generalized glycogen storage disease, von Gierke's Disease and Cori's Disease (limit dextrinosis).

Recently Mostafa (1970) presented a case of glycogenic cardiomegaly in a dog. Clinically the condition was diagnosed as a combination of tonsilitis, oesophageal dilatation and myocarditis, with characteristic symptoms of difficulty in deglutition, vomiting and unthriftiness. By light microscopy, abundant glycogen was demonstrated in widespread locations, such as heart, liver, lung, oesophagus, brain, kidneys, arterial walls and capillaries. The case was believed to conform to the classic form of Pompe's Disease.

Sandstrøm et al. (1969) reported a case of central nervous system glycogenosis occurring in a cat. It was an incidental observation in a material processed for other purposes, and history of the clinical disease and possible accumulation of glycogen in other organs were unknown. The central nervous system findings in the cat corresponded to what is seen in Pompe's disease in man.

Manktelow \& Hartley (1975) described a type of generalized glycogen storage disease occurring in a flock of Corriedale sheep in New Zealand. The usual clinical signs were incoordination, lethargy, loss in condition and drooping ears. Some of the affected animals were observed to drop dead on excertion. The glycogen deposits seemed to be most extensive in the brain and cord and in the cardiac, striated and smooth musculature, the appearance and distribution of the lesions closely resembling glycogenosis as seen in Pompe's disease. 
The purpose of this presentation, in view of the rarity of information about GSD in animals which may serve as a valuable model for the disease in man, is to report four cases of glycogen storage disease in the dog. Clinical data, gross pathology, light and electron microscopy findings will be presented in this paper.

\section{MATERIALS AND METHODS}

The four cases were all demonstrated in female German Shepherd dogs received for post-mortem examinations. Tissues from the different organs were collected in $\mathbf{1 0} \%$ neutral formalin, dehydrated and embedded in paraffin for sectioning. The following staining methods were used: Haematoxylin and eosin (HE), van Gieson (v.G.), Best's carmine staining and periodic acid Schiff (PAS). Specificity of the PAS reaction was confirmed by diastase-digestion performed on parallel sections. Unfixed frozen sections were also made and stained with Sudan III and PAS.

For electron microscopy, pieces of the liver from one of the dogs (case 1) and from liver, kidney, heart and brain from another (case 4) were fixed in $3 \%$ glutaraldehyde with macrodex, postfixed in $1 \%$ osmium tetroxide in Millonig's phosphate buffer (Millonig 1961), dehydrated in acetone and embedded in araldite. Ultrathin sections were cut on a LKB-ultrotome, collected on copper grids coated with formvar films and stained with $5 \%$ aqueous uranyl acetate (Watson 1958) followed by lead citrate (Reynolds 1963). The electron microscope used was a Siemens Elmiskop 1A.

Control preparations were obtained from dogs killed in accidents or on purpose for other reasons than disease.

\section{Clinical observations}

\section{RESULTS}

Ca s e 1. A female German Shepherd dog, 15 $\frac{1 / 2}{2}$ months old. It showed the first symptoms at the age of about four months manifested by depression and muscular weakness. It had difficulties in walking, got easily tired and would lay down even after moderate exercise. When rising again it would walk like "a drunk man". The dog gradually became unthrifty and showed more retarded mobility. Roentgenography for suspected hipjoint dysplasia revealed no abnormality and the dog was given $2 \mathrm{ml}$ 
Afi B total forte ${ }^{\star}$ and $25 \mathrm{mg}$ Prednisolone. Treatment was followed by disappearance of symptoms, the dog being able to move normally for a few days. About a week later, however, the symptoms reappeared. The heart and lungs were functioning normally, but the liver region of the abdomen was distended. As the inability to move became more prominent, the dog was ultimately euthanized.

C a s e 2. A female German Shepherd dog, $9 \frac{1}{2}$ months old. It had been unthrifty from puppyhood, was slow growing and had an abnormal increase in belly width. A liver tumour was suspected and the dog was euthanized.

C a s e 3. A female German Shepherd dog, 101/2 months old. The dog had shown polydipsia since puppyhood, had been slow growing, weak and slender. The owner had observed an increasing distention of the dog's belly. One day it started to vomit and had diarrhoea. Clinical examination revealed: Temp. $40.5^{\circ} \mathrm{C}$, pulse rate 174 and respiration 56. Urine: Prot. + , bile pigment ++ . The dog was relieved of 31 of ascitic fluid. The ascites reoccurred shortly and the dog was euthanized.

C a s e 4. A female German Shepherd dog, 15 months old. It had shown symptoms since being a puppy, manifested by flaccidity and muscular weakness, especially noticeable after exercise. It would become recumbent and could not rise before some time had passed. Appetite had been good. The belly was distended and an enlarged liver was palpable. GSD was suspected. Blood examinations: N.P.N. $42 \mathrm{mg} / 100 \mathrm{ml}$ blood, blood sugar $51.6 \mathrm{mg} /$ $100 \mathrm{ml}$ blood, cholesterol $198 \mathrm{mg} / 100 \mathrm{ml}$ serum, aceto-acetate $0.17 \mathrm{mg} / 100 \mathrm{ml}$ serum, urea $38.6 \mathrm{mg} / 100 \mathrm{ml}$ serum, GOT 58.5 $\mathrm{mU} / \mathrm{ml}$ serum, GPT $302.0 \mathrm{mU} / \mathrm{ml}$ serum. Glucagon and epinephrine tests were performed. Glucagon ${ }^{\star \star} 0.50 \mathrm{mg}$ was given intravenously. Blood was drawn before and every $30 \mathrm{~min}$. after the injection for $2 \mathrm{hrs}$. For the epinephrine test, $1 \mathrm{ml}$ of a $1 \%$ solution was given as intramuscular injection. Blood was drawn every $30 \mathrm{~min}$. for $3 \mathrm{hrs}$. The galactose tolerance test was performed by injecting $1 \mathrm{~g}$ galactose $/ \mathrm{kg}$ body weight intravenously during $3 \mathrm{~min}$. and blood was drawn every $5 \mathrm{~min}$. for $45 \mathrm{~min}$.

* A/S Farmaceutisk Industri, Norway.

* * Novo Industries, Copenhagen, Denmark. 
The glucagon and galactose tests behaved in the same way in diseased and control dogs. The epinephrine test did not give rise to increased blood sugar in the diseased dog after $30 \mathrm{~min}$. as compared with the control which showed a rise of $50 \%$. After $1 \mathrm{hr}$. a reduced rise was observed in the diseased dog. Unfortunately, the dog got a phlegmonous periphlebitis with septicemia and died very suddenly. The glucagon and epinephrine tests could therefore not be done on the fasted animal.

\section{Gross pathology}

The two younger animals (case 2 and 3 ) were in very poor nutritional state. Case 4 was slightly icteric and had a severe subcutaneous phlegmonous inflammation at the left rear leg (see above). The lymph nodes seemed moderately enlarged in all the dogs, and especially the portal lymph nodes. Also the tonsils and the lymphatic nodules in the caecum were swollen in case 1 . All the dogs had a slightly hypertrophic myocardium which had a glistening, dark, red-brown colour. The most dramatic lesion, howewer, was the huge enlargement of the liver, the weight varying from $2.03 \mathrm{~kg}$ in case 3 to $3.6 \mathrm{~kg}$ in case 4 . Expressed in percentage of body weight it ranged from $8.8 \%$ in case 1 to $16 \%$ in case 2 . The colour of the liver was intense red-brown and glistening, the texture moderately increased. In two of the cases the liver had small fibrotic indentations giving the organ an uneven surface. In case 3 there was about 21 of clear, yellow, ascitic fluid.

\section{Microscopic pathology}

Liver. The histological changes were characterized by greatly enlarged liver cells of relatively uniform size. The foamy cells were pale staining and possessed well demarcated cell membranes (Fig. 1A). No lipid material could be revealed in frozen sections stained with Sudan III. The liver cell nuclei were usually eccentrically located and contained prominent nucleoli and conspicuous marginal chromatin. The lobular architecture was accentuated because of a slight fibrosis being mostly perilobular, but also noticeable as strands of fibrous tissue into the lobules and around some of the central veins, thereby causing a slight pseudolobulation in some areas. Some small infiltrations of mononuclear cells could be seen, but in one case (case 1) neutrophils were predominent. Best- and PAS-stained sections revealed 

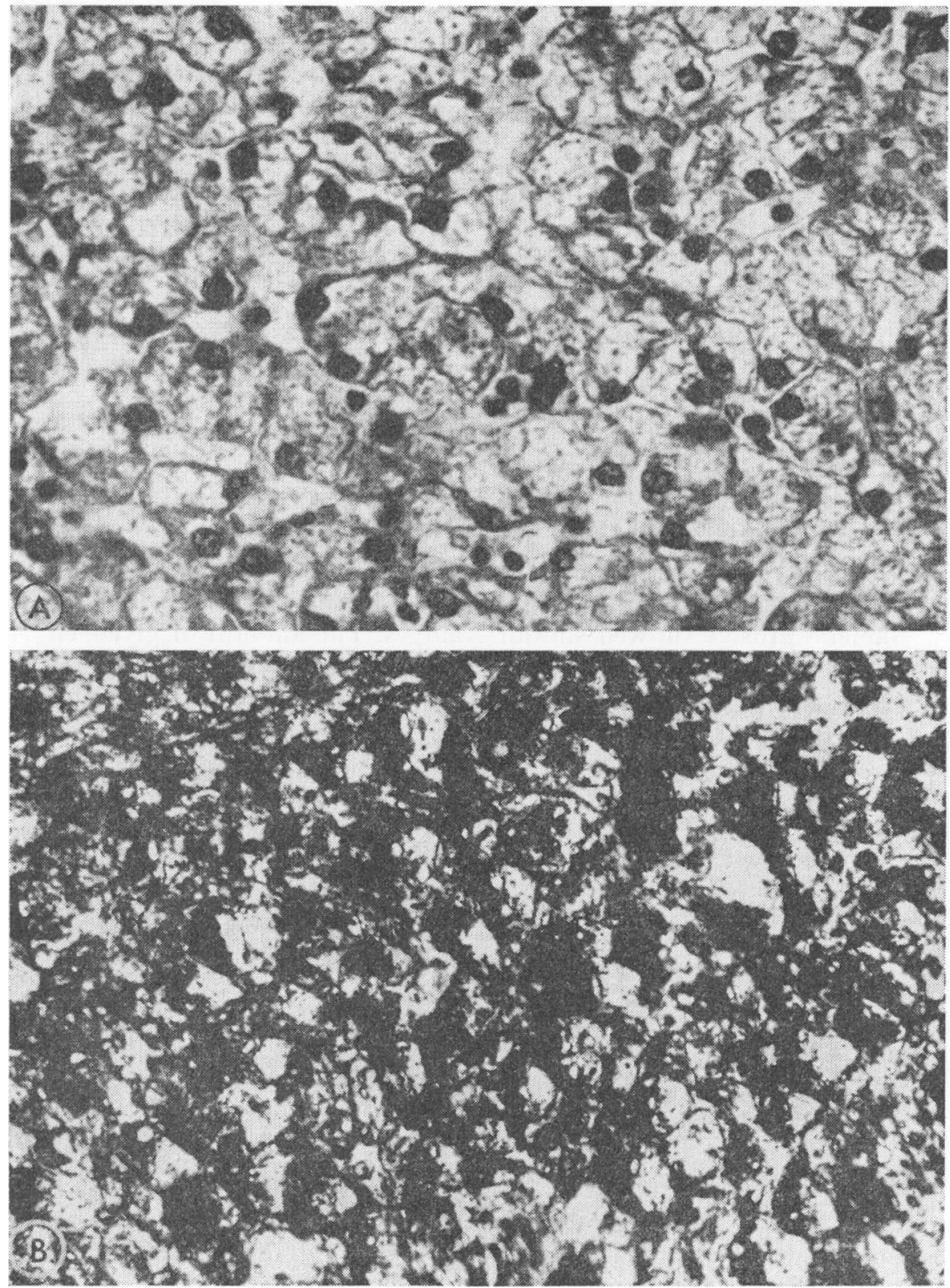

Figure 1.

A. Vacuolated liver cells of increased size. Cell membranes are very distinct. Note mostly eccentrically located nuclei containing prominent nucleoli and marginal chromatin. $\mathrm{HE}, \times 357$.

B. Abundant glycogen in liver cells. Note some heavily stained cells. Unfixed frozen section. PAS, X 145 . 
a heavy accumulation of a red, granular substance within the cytoplasm of the hepatic and van Kupffer cells (Fig. 1B) which disappeared after diastase digestion.

$\mathrm{K}$ idneys. No pathologic accumulation of glycogen was seen. In cases 1, 2 and 3 some protein casts were observed in the capsular spaces and tubules. There were some slight signs of degeneration and desquamation of cells, especially in the proximal tubules, and in cases 2 and 3 a moderate increase in interstitial connective tissue was discernable. In case 3 there was also some glomerulosclerosis.

M u s l e $t$ is u e s. The cardiac muscle fibres were lighter than usual in HE-sections, they were vacuolated, the bigger vacuoles being mostly located around the nuclei or just inside the carcolemma. In Best- and PAS-stained sections an unusually rich, but uneven accumulation of granular glycogen was found, in some places so rich that red, homogenous flakes were formed. Skeletal muscle showed similar changes. The amount of glycogen showed, however, a great variation from muscle to muscle being especially abundant in the diaphragm in one of the cases. Smooth muscle was also affected by an increased accumulation of glycogen. This was seen in media of the vessels of all the organs examined, in muscularis of the intestine, the urinary bladder and the bronchi and bronchioles.

S p l e e n a n d ly m p h od es. No accumulation of glycogen was seen except in smooth muscle cells of the vessels and trabeculae.

P a n c reas. There was some accumulation of glycogen at the base of the acinar cells and between the acini as well as in the duct system. Nothing was seen in the islets of Langerhans.

The thyreoid, parathyreoid, suprarenales and bon e marow showed no changes.

$\mathrm{Nervous}$ s y t e m. A variable amount of glycogen was found deposited in occasional nerve cells of the brain and spinal cord. Deposits were quite frequent in pyramidal cells of the cerebral cortex as well as in the Purkinje cells, but seemed to be most extensive in some nuclei of the brain stem and the ventral horn cells throughout the spinal cord (Fig. 2A and B). Considerable glycogen deposits could also be found in the dendrites and in glial cells. Granular glycogen could easily be seen in the leptomeninges. 


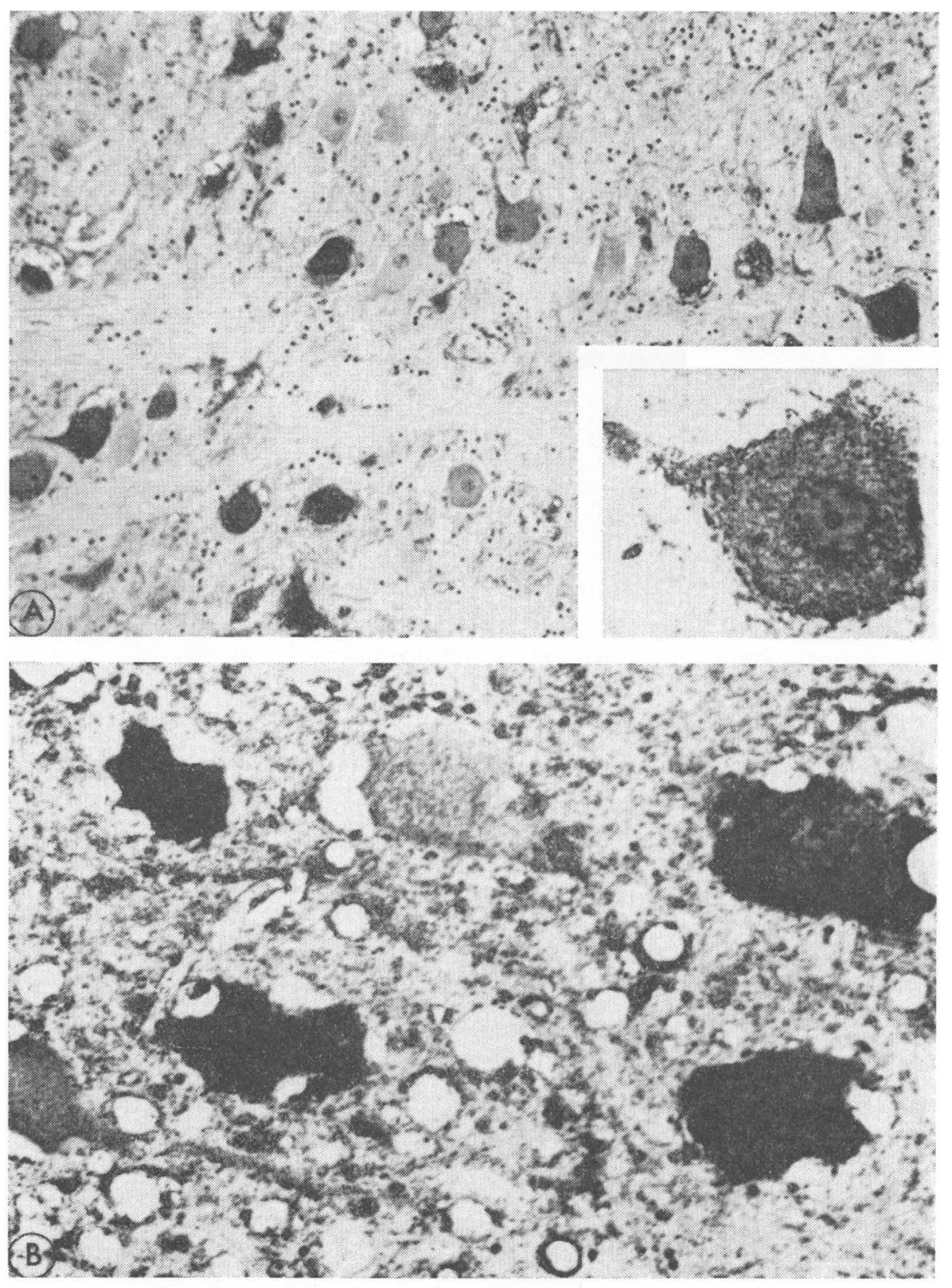

Fig u r e 2.

A. Marked glycogen deposition in nerve cells of the medulla oblongata. Inset. At higher magnification the granular pattern of the glycogen is evident in the nerve cell including its processes. PAS, $\times 55$, Inset $\times 357$.

B. Granular glycogen deposition in the nerve cells and in the neurophil of the heavily vacuolated spinal cord. PAS, $\times 357$. 


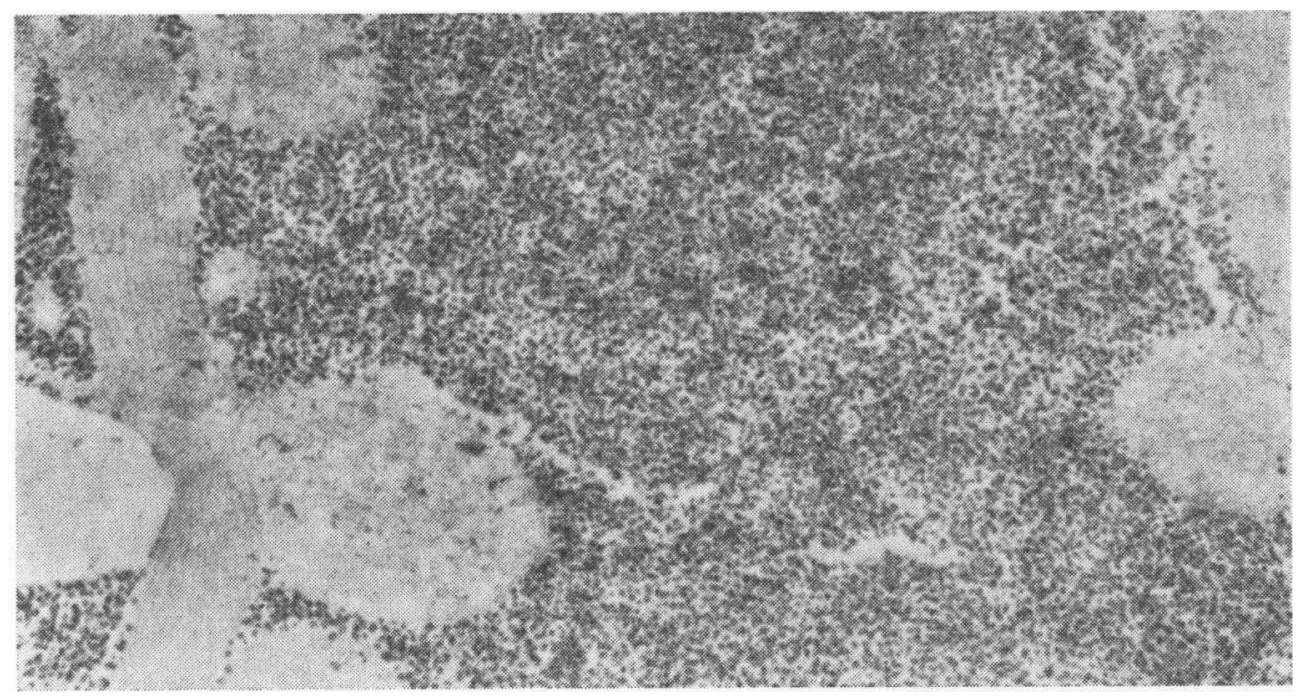

Figure 3. Abnormal high amounts of granular glycogen in the myocardium separating the myofibrils. $\times 30,000$.

\section{Electron microscopy}

A heavy increase of cytoplasmic glycogen was observed in the hepatic cells, muscle fibres of the heart (Fig. 3), and in nerve and glial cells of the brain (Fig. 4). The glycogen was lying freely dispersed in the cytoplasm in a monogranular ( $\beta$-particles) and multigranular ( $\alpha$-particles) form. In the muscles, however,

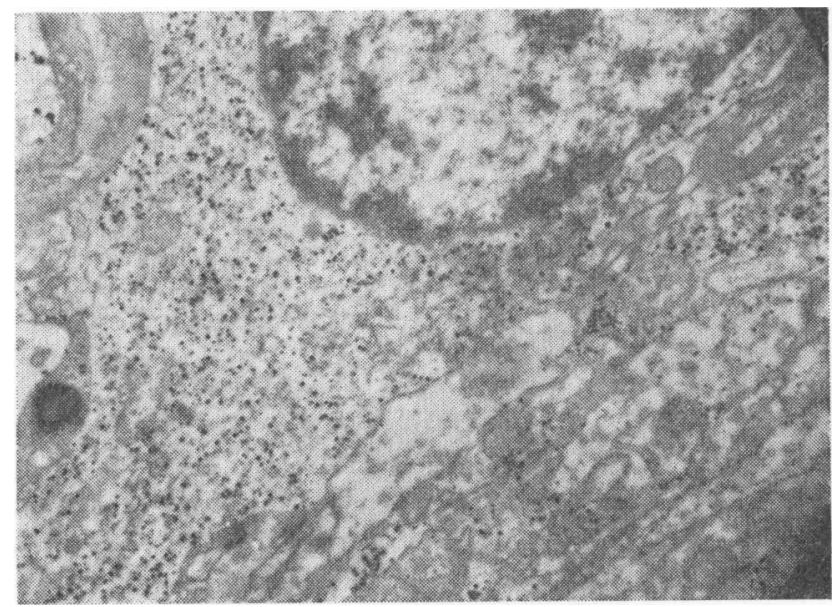

Fig u r e 4. Cerebellum. A glial cell containing an increased amount of glycogen freely dispersed in the cytoplasm. $\times 6000$. 


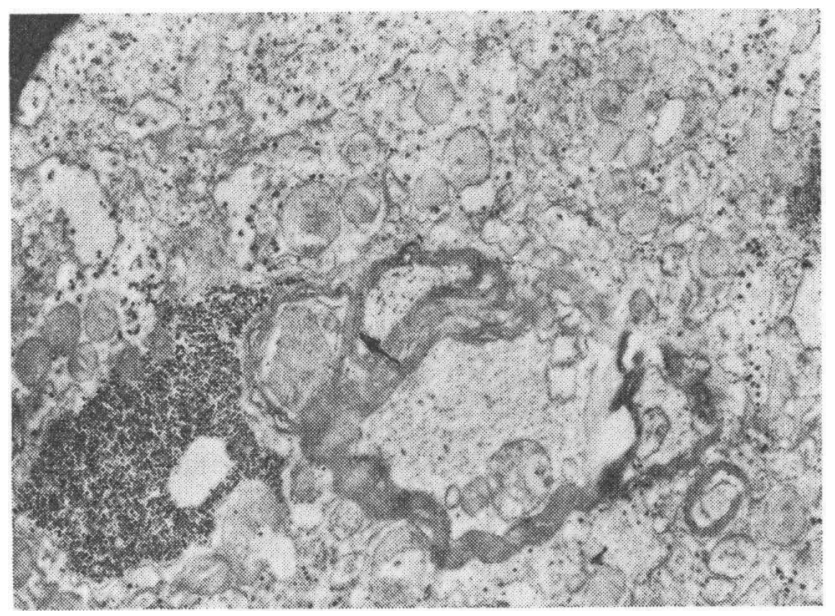

F i g u r e 5. Medulla oblongata. The glycogen is partly dispersed and partly more concentrated, but without any "bag" arrangement. The somewhat deteriorated myelin sheats with dark, streaky, interlamellar material (arrow) is demonstrated. $\times 10,000$.

it seemed to be mostly of the monogranular type, lying between the myofibrils and thus putting them apart (Fig. 3). In the nerve cells the deposits were also located to the fibres. Interlamellar dark streaks were observed in the often somewhat deteriorated and split myelin sheats (Fig. 5). Glycogen depasits were in rare occasions seen in the nuclei of glial cells.

\section{Genetics}

The dogs came from different breeders. We have no information about occurrence of the disease in sisters or brothers or other family members of the dogs with GSD. The restriction of the disease to females may be insignificant because of the few cases examined. In our efforts to investigate the pedigree of the dogs, a certain male dog was traced both on the mother and the father side of three of the cases. In the fourth one (case 4) this male dog was found only on the father side.

\section{DISCUSSION}

The present investigation has disclosed a type of generalized glycogenosis occurring in German Shepherd dogs. The similarity of the anatomical findings in the four cases highly indicates 
that they are of the same type of GSD and developed through the same type of enzyme defect. We are aware of only one prior publication of glycogenosis in dogs giving a sufficiently detailed description of the pathology. It is the article of Mostafa (1970) on a case occurring in a Swedish Lapland male dog. The deposits of glycogen in this dog were also of a generalized type, but differed from our cases by showing a strikingly enlarged heart and some glycogen deposition also in the kidneys. Our dogs had no clinical signs of heart involvement and no significant cardiomegaly.

It might therefore be better to try to discuss our cases in relation to the different types of glycogenosis occurring in man. Looking at the location of the deposits of glycogen, the generalized form of glycogenosis in man, Type II, or Pompe's Disease seems to be the most related. In the human disease it has been demonstrated that some of the deposits are located in vacuoles or single membrane-surrounded "bags", indicating a lysosomal storage. In our cases the glycogen was found freely dispersed in the cytoplasm and no "bag" formation was observed. Nor did we see a pronounced cardiomegaly with clinical signs of cardiac failure, which is conspicuous in Pompe's Disease. Field (1968) indicated that some authors have divided Pompe's Disease into cases with primarily cardiac and cases with primarily neuromuscular involvement. Imbecility and hypotonia of muscles are the predominant symptoms of the latter. In our cases muscle hypotonia was seen, but we have no information about the occurrence of brain symptoms other than some incoordination of movements, even though the glycogen deposits in nerve cells could be significant.

There are five other types of glycogenosis in man where hepatomegaly can be a significant symptom. It is in Type I or von Gierke's Disease, Type III or Cori's Disease, Type IV or Andersen's Disease, Type VI or Hers' Disease and Type VIII.

Looking first at Type I, the glycogen deposits are prominent in the kidneys besides in the liver. In our cases no deposits could be demonstrated in the kidneys.

In Type III the hepatomegaly with some mild cirrhosis and growth retardation may be striking. Growth retardation was seen in two of our cases, hepatomegaly in all. Fibrotic changes of the liver were also demonstrated. Muscle as well as cardiac involvement with slight cardiomegaly is often a part of the syndrome in 
Type III in humans. These organs were also affected in our cases. A discrepancy is, however, the more widespread distributions of the glycogen deposits in the dogs.

In Type IV there is likewise hepatomegaly with cirrhosis, but here the spleen is also enlarged. The glycogen content in the tissues is usually not increased in this type. It is, however, of abnormal structure having long outer branches similar to amylopectin.

In Type VI and Type VIII only the liver is involved, no pathologic accumulations of glycogen are found in the other organs.

When clinical symptoms are considered the hepatic and muscle involvement were most conspicuous. This would fit best with a Type III or Cori's Disease, but could also be suggestive for Type II. The glucagon and epinephrine tests do not give clear information concerning these two types as they were not done on the fasted dog, but seen in connection with the normal results of the galactose tolerance test, they exclude Type I or von Gierke's Disease. The normal contents of cholesterol and acetoacetate point to the same conclusion. The high serum transaminase levels would fit in with one of the two types III or IV where the glycogen deposits are of abnormal structure and the tissue reaction in the liver indicates tissue damage. Two of the dogs were in a slightly icteric condition which also suggests liver involvement. The kidney lesions especially noticeable in case 3 are possibly not to be looked upon as part of the GSD-complex.

The brief relief of clinical symptoms seen in case 1 after treatment with Afi B total forte and Prednisolone could possibly be explained by the general stimulus of the carbohydrate metabolism by vitamin $B$ and a stimulatory effect of the glucocorticoid on the synthesis of key gluconogenic enzymes.

Putting the different considerations together, it seems most likely that the disease in the dogs could be related to Type III or Cori's Disease, but with a wider organ distribution of the defect in glycogen metabolism. It is, however, necessary to do structure analysis and enzyme investigations to come to a definite conclusion. The results of such investigations are given by $\check{C} e h$ et al. (1976).

\section{ACKNOWLEDGEMENT}

We gratefully acknowledge the help given by Dr. Per Nafstad in the electron microscopy work. 


\section{REFERENCES}

Bardens, J. W.: Glycogen storage disease in puppies. Vet. Med./Small Animal Clinician 1966, 61, 1174-1176.

Bardens, J. W., G. W. Bardens \& B. Bardens: Clinical observation on a von Gierke-like syndrome in puppies. Allied Vet. 1961, 32, 4-7.

Čeh, L., J. G. Hauge, R. Svenkerud \& A. Strande: Glycogenosis type III in the dog. Acta vet. scand. 1976, 17, 210-222.

Cori, G. T.: Biochemical aspects of glycogen deposition disease. Mod. Probl. Pädiat. 1957, 3, 344-358.

di Sant 'Agnese, P. A.: Disease of glycogen storage with special reference to cardiac type of generalized glycogenosis. Ann. N.Y. Acad. Sci. 1959, 72, 439-450.

di Sant'Agnese, P. A., D. H. Andersen \& H. H. Mason: Glycogen storage disease of the heart. II. Criterical review of the literature. Pediatrics 1950, 6, 607-623.

Field, R. A.: The glycogenoses: von Gierke's disease, acid maltase deficiency, and liver glycogen phosphorylase deficiency. Amer. J. clin. Path. 1968, 50, 20-28.

Hers, H. G.: Glycogen storage diseases. In Levine, R. \& R. Luft, eds.: Advances in Metabolic Disorders. Acad. Press, Inc. N.Y. 1964, Vol. 1, 2-40.

Howell, R. R.: The glycogen storage diseases. In Stanbury, J. B., J. B. Wyngaarden \& D. S. Fredrickson, eds.: The Metabolic Basis of Inherited Disease. 3rd Ed. McGraw-Hill, N.Y. 1972, 149-173.

Hug, G., J. C. Garancis, W. K. Schubert \& S. Kaplan: Glycogen storage disease, Types II, III, VIII and IX. Amer. J. Dis. Child. 1966, $111,457-474$.

Manktelow, B. W. \& W. J. Hartley: Generalized glycogen storage disease in sheep. J. comp. Path. 1975, 85, 139-145.

Millonig, G.: Advantage of a phosphate buffer for $\mathrm{OsO}_{4}$ solution in fixation. J. appl. Physics 1961, 32, 1637.

Mostafa, I. E.: A case of glycogenic cardiomegaly in a dog. Acta vet. scand. 1970, 11, 197-208.

Reynolds, E. S.: The use of lead citrate at high pH as electron opaque stain in electron microscopy. J. Cell Biol. 1963, 17, 208-212.

Sandstr $\phi m, B$., J. Westman \& P. A. ökerman: Glycogenosis of the central nervous system in the cat. Acta neuropath. (Berl.) 1969, 14, 194-200.

Watson, M. L.: Staining of tissue sections for electron microscopy with heavy metals. J. biophys. biochem. Cytol. 1958, 4, 475-478.

\section{SAMMENDRAG}

Glykogenose hos hund.

Det er beskrevet 4 tilfeller av en generalisert form for patologisk glykogenavleiring i organene hos hund. Alle var tisper og av Schäfer rase. Symptomene ble observert allerede fra ca. 2 måneders alder og 
tiltok i løpet av måneder. De besto i muskelsvekkelse, slapphet, tiltagende bukomfang og hos to av dyrene dårlig matlyst og nedsatt tilvekst. Ved obduksjon fantes en meget sterkt forstørret og svakt fibrotisk lever. Unormalt store mengder av en kornet substans som histokjemisk forholdt seg som glykogen fantes avleiret $i$ cellenes cytoplasma i lever, all tverrstripet og glatt muskulatur, nerveceller og gliaceller. Substansen lå fordelt i cytoplasma uten tegn til lysosomal leiring og fantes $i$ monogranulær form og $i$ rosetter. Lidelsen hos hund synes ikke å være helt lik noen av de beskrevne typer av glykogenose hos menneske, men synes å stå nær Type III eller Cori's sykdom. Strukturanalyse av den kornede substans og enzymatiske undersøkelser er utført av Ceh et al. (1976).

(Received March 19, 1976).

Reprints may be requested from: R. Svenkerud, Veterinary College of Norway, Box 8146, Oslo-Dep., Oslo 1, Norway. 